口腔に発生した線維性組織球腫の 2 例

堀越勝・原利通・勝村浅樹・小野富昭

南雲正男*.名倉英明・曽田忠雄・伊藤秀夫

\title{
Two cases of fibrous histiocytoma of oral region
}

\author{
Masaru Horikoshi - Toshimichi Hara - Asaki Katsumura - Toaki Ono \\ Masao Nagumo* - Hideaki Nagura - Tadao SodA - Hideo ItoH
}

緒

言

線維性組織球腫は組織球の増殖を主体とする腫瘍であ るが, 多様な組織像を示すことから, 病理学的名称, 分 類および位置づけに関してはまだ問題が多いようであ る. 本腫渲の口腔領域への発生は，かなりまれなよう で，われわれが涉猟し得た報告症例数は現在までに 11 例1 6) を数えるのみである。最近，われわれは良性と悪 性の本腫場のそれぞれ 1 例を経験したので，その概要を 報告し, あわせて口腔領域における本腫瘍について文献 的考察を試みた。

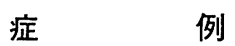

\section{症例 1 \\ 患 者: 32藏 女性. \\ 初 診: 昭和 51 年 2 月}

主 訴：口底部の腫瘤および発音障害。

既往歴：初診時の胸部X線写真で, 左側第 6 および第 7 肋間部に石灰化した結核病巣と思われる所見が認めら れたが，患者に結核罹患の記憶はなく，汪とんど無症状 で経過し, 治癒したものと思われた。 そのほかには特記 すべき事項はない。

現病歴: 昭和34年ごろ, 舌の左側下面の無痛性小腫瘤 に気づいた，腫瘤は徐々に增大して10年ぐらいの間にピ ンポン玉大となり, 最近になって増大傾向が速まったの

東京医科菌科大学歯学部第 2 口腔外科学教室（主 任 : 伊藤秀夫教授)

* 昭和大学菌学部第 2 口腔外科学教室（主任：南雲 正男助教授)

The Second Department of Oral Surgery, Faculty of Dentistry, Tokyo Medical and Dental University (Chief: Prof. Hideo Itoh)

* The Second Department of Oral Surgery, Faculty of Dentistry, Showa University (Chief: Assist. Prof. Masao Nagumo)

受付日：昭和 52 年 11 月 25 日
で，昭和48年 8 月】に当科を受診した。そのときには 舌の左側面から口底にかけて境界明膫な内向性のやや硬 いクルミ大の腫瘤が形成されていた。患者は妊娠 2 か月 であったので，分婏後に手術を行うことにし，約 2.5 年 後の昭和 51 年 2 月【に腫瘤の急速な增大を訴えて再び 当科を訪れた。

現 症：体格中等度, 栄養状態良好で, 全身的には特 に異常は認められない。また開口障害および咬合の異常 はなく，顎下部から頸部にかけてのリンパ節腫脹もな い. 舌の左側から口底, 臨下にかけて直径約 $6 \mathrm{~cm}$ のほ ぼ球状の内向性の腫瘤が形成されていた，舌背はやや上 方に膨隆して拈り，願下部にも膨隆が認められた（写真 1,2). 腫瘤の前半分は弾性軟, 後半分, 寸なわち舌根 および願下に面する部分は弾性硬で， 2 種類の腫瘤が合 併しているような印象をらけた。被覆粘膜および皮成に は特に異常はみられなかった。舌は後上方に举上されて おり，著明な発音障害および軽度の燕下障害が認められ た. 腫瘤前部の穿刺によって約 $5 \mathrm{ml}$ の暗黒赤色の血液 様液体が吸引された。底部のX線写真では小石灰化物 の存在を思わせる所見が認められた。

臨床検査結果：一般血液検査，血清生化学的検査およ び血清学的検查の結果はいずれも正常で，梅毒反応も陰 性であった。

手術所見および経過：口底部の良性腫瘍の臨床診断 で，5月【に GOF による全身麻酔下に手術を行っ た. 切開線を口底の顎下腺管の内側に設定し，鈍的に剝 離し摘出した。腫湯は比較的厚い被膜で囲まれ，大部分 は舌および口底の筋層内にあったが，周囲との境界は明 瞭で，全摘出された，腫瘍の表面には多数の抎張した静 脈性の血管が瘉着していた，摘出された腫瘍の大きさは 約 $6 \times 5 \times 5 \mathrm{~cm}$ で, その割面は充実性で, やや黄色を呈 していた（写真 3，4）. 術後約 1 年 6 か月の現在, 再発 の徵候は全くなく，また発音および燕下障害もみられ ず，経過は良好である。

病理組織学的所見および診断：摘出物は比較的厚い結 合織性の被膜で包まれた実質性の腫瘍で，その大部分は 類円形の組織球の密な增殖からなっており(写真 5，6)， 


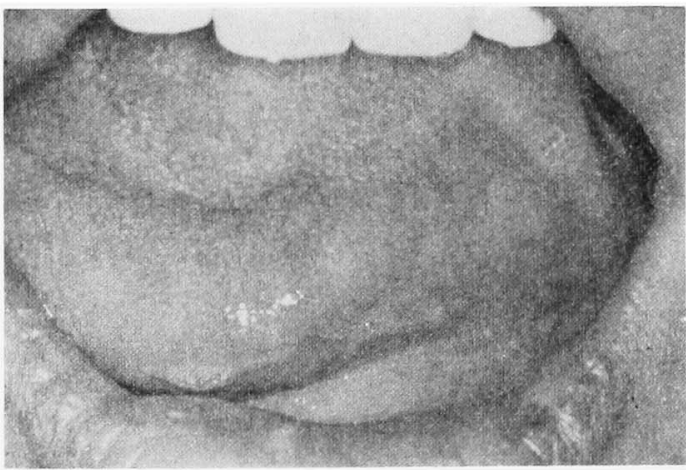

写真 1 舌拉よび口底部の膨隆

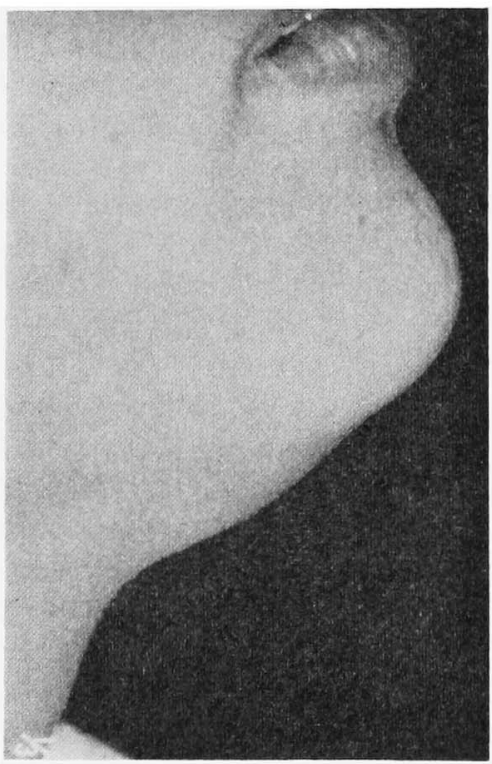

写真 2 碩下部の膨隆

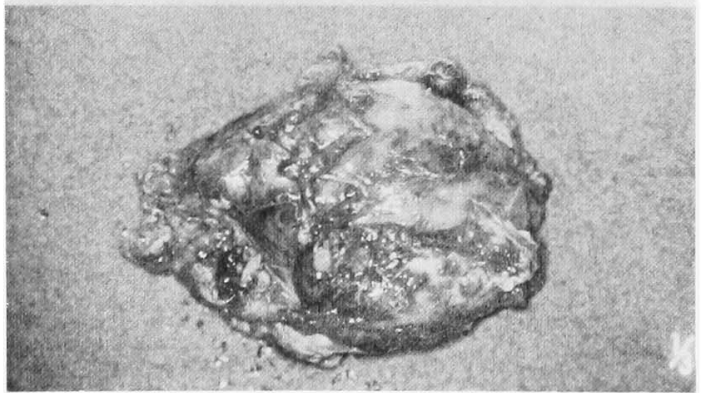

写真 3 摘出された腫湯

一部分は平行的に配列した線維芽細胞の増殖からなって いた（写真 7 ）. 全般的に線維の形成は著明でなかった

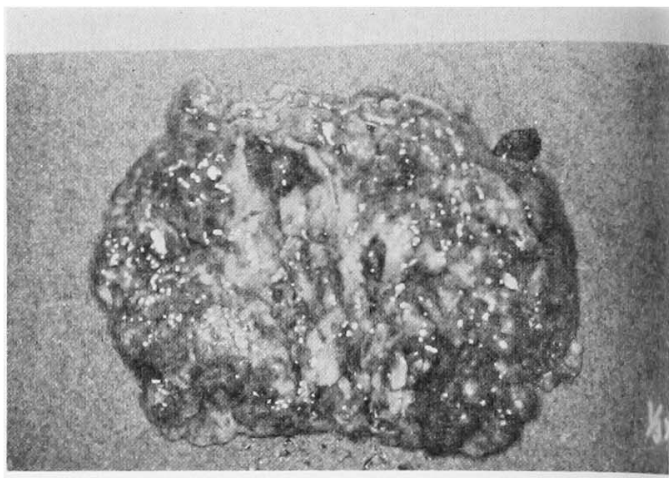

写真 4 尰湟の割面

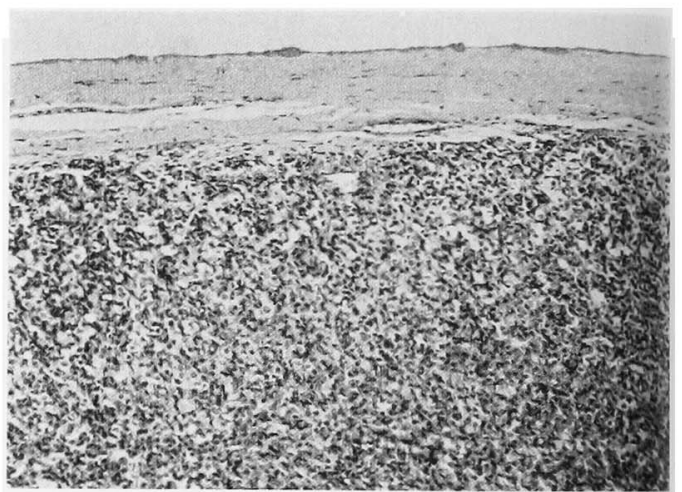

写直 5 組織学的所見 H-E 染色 $\times 120$

睡㻛は被膜を有し，類円形の組裁球が密に增殖して いる。

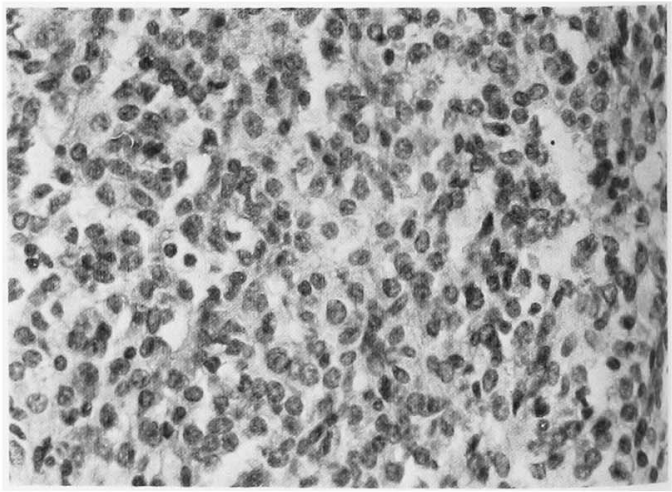

写真 6 組織学的所見 H-E 染色 $\times 400$ 組織球が增殖している部分。

が，銀染色で好銀線維が多数認められた（写真 8).

組織球には細胞質の明瞭なるのと，空胞の著明なすの とがあった，腫湟細胞には核の多形性も多少みられた が，異型性および核分裂像は明らかではなかった。 


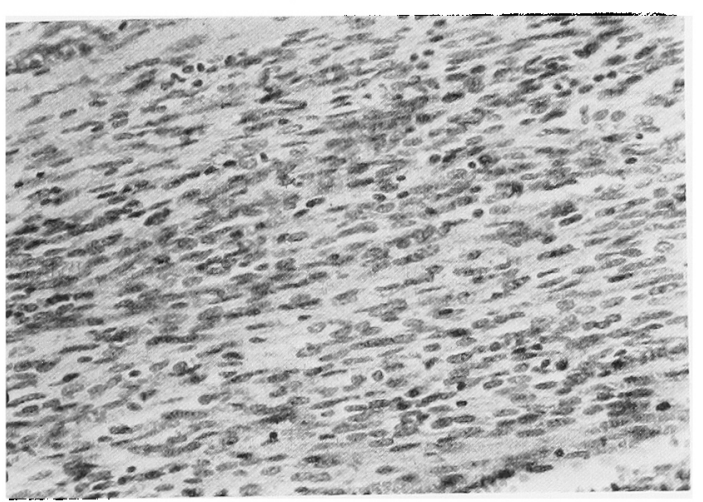

写真 7 組織学的所見 H-E 染色 $\times 120$

線稚芽細胞が增殖している部分.

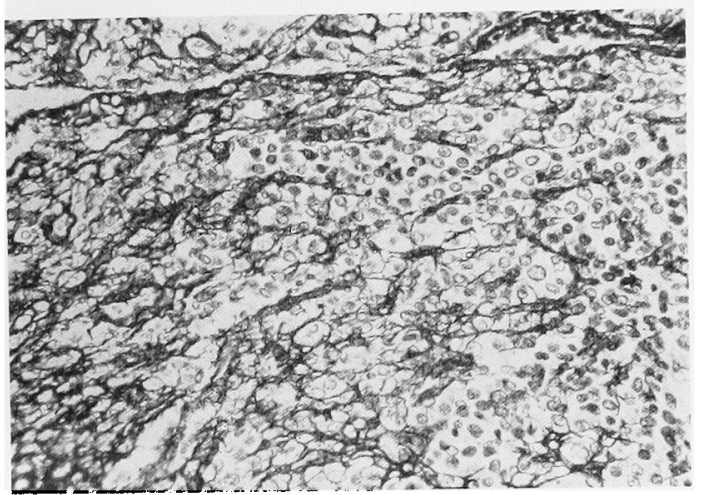

写真 8 組織学的所見 銀染色 $\times 120$

お，核が環状に配列した多核巨細胞と思われる細胞が散 見され（写直 9)，また oil red O 染色陽性の細胞むみ られた（写真 10）.

以上の所見から, 本学口腔病理学教室で良性線維性組 織球尰と診断された。

\section{症例 2}

患 者: 50歳 男性.

初 診: 昭和52年 6 月日.

主 訴：上額前歯部の尰瘤および出血.

既往歴：24歳㔚よび29藏のときに肝炎に罹患したが， 見在は治洕している。そのはかに特記すべき事項はな w.

現病歴 : 昭和51年 4 月ごろ， 1 部の唇側歯肉の暗紫 色，小豆大の腫瘤に気づ，齿科医院で 1/を技去され たが, 治癒不良のため某大学病院を訪れ，埋伏過剩歯の 存在を指摘されて，7月に埋伏贯拔去掞よび腫瘤摘出の 手術をらけた，術後経過が良㧠であったので， $\underline{3}|\sim| \underline{2}$ の橋義菌が装着された。しかし，9月には前と同じ部位 に再び尰瘤が形成された，52年 2 月および 4 月にす手術 をらけたが，再発し，しかも口蓋歯肉にも腫瘤を生じ，

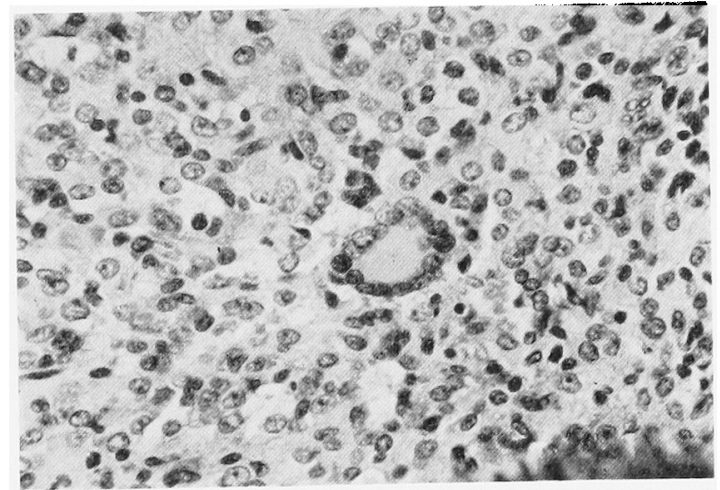

写真 9 組織学的所見 H-E 染色 $\times 400$ 核が環状に配列した巨細胞。

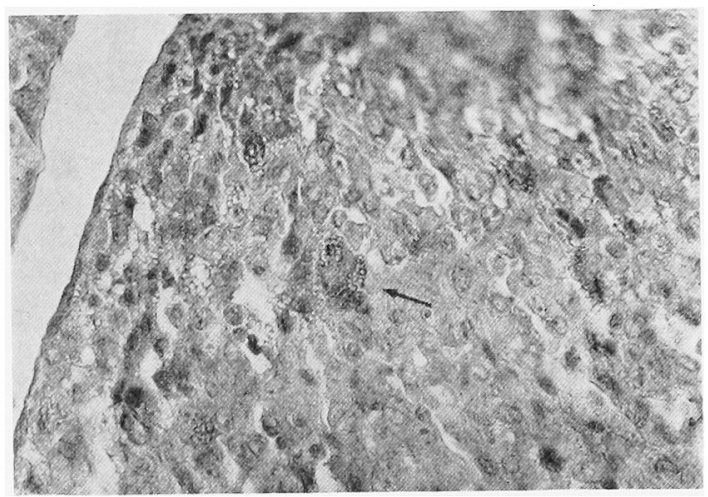

写真 10 組織学的所見 oil red $O$ 染色 矢印は陽性の細胞.

增大㑯向を示すととるに出血するようになったので，紹 介されて 6 月日日，当科を受診した。

現 症：体格および栄養状態ともに良好で，全身的に は特に異常は認められない，両側の䫇下部に小指頭大の リンパ節が触知されたが，可動性で疼痛はない，21 部 （欠損）の唇・口蓋の両側にンラマメ大の暗紫色の腫瘤 が形成されていた，腫瘤は表面平滑，弾性㯖であり，小 量の出血が続いていた（写真 11），尰湯の増大はきわめ て急速で，約 1 週間の間に，唇側尰湯は $3.5 \times 2.7 \times 2.2$ $\mathrm{cm}$ ，口蓋側尰演は $1.8 \times 1.3 \times 1.0 \mathrm{~cm}$ の大きさとなり， ロ外に突出した腫瘍のため，口唇の閉鎖が不可能になっ た.

X線所見：昭和51年 4 月に撮影されたX線フィルムて は1根尖部にV字形の異常な根尖吸収像が認められ

（写真 12），また 8 月の橋義䨑装着時のX線フィルムで は21 歯槽突起部の骨吸収像がみられた５2年6月の当 科入院時のX線フィルムでは，さらに広範囲のぴまん性 の骨破䧇像が認められた。

監床検查結果：一般血液検查, 血清生化学的検查はい 


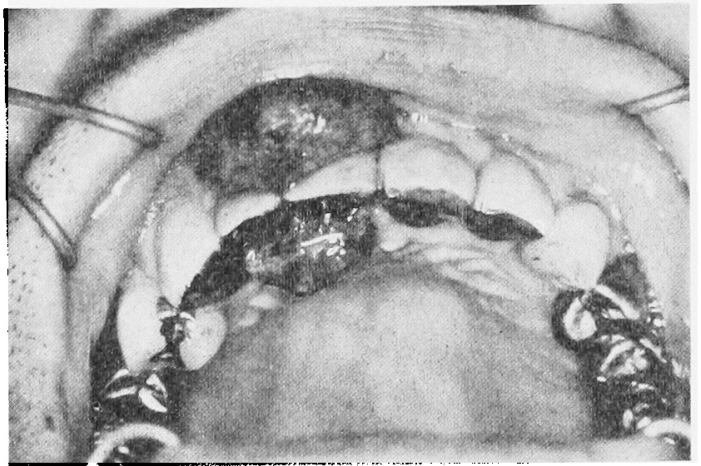

写真 1121 部の尰湐（初訩時）

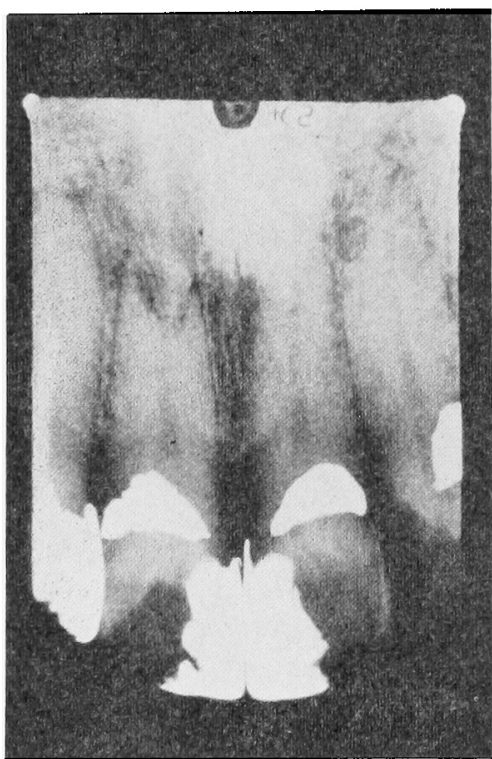

写真 1251 年 4 月撮影のX線フィルム

ずれも正常で，梅毒反応も陰性であった，兔疫学的検査 では DNCB 乱よび PPD 反応はとると陽性, リンパ球 幼若化反応拉よびリンパ球の subpopulation る正常範囲 内であった。

手術所見および経過：6月口日の組織生検で悪性線維 性組織球腫が疑われたので，口日に入院し，放射線治療 を開始し，回日までに合計 1,500 rads のベータートロ ン照射が行われたが，腫堭には影響がみられず，ますま す增大するので（写真 13），外科的に除去の方針を決定 した。 6 月曰日, GOF 全身麻醉下儿, 口内法汇より上

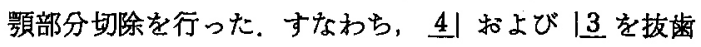
し，右側は中番甲介，左側は下算甲介を含む高さで，口

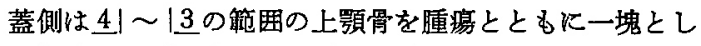
て切除した（写真 14，15）. $3+2$ 粀慒突起部は汪之

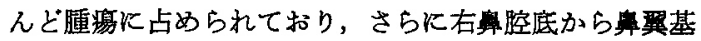

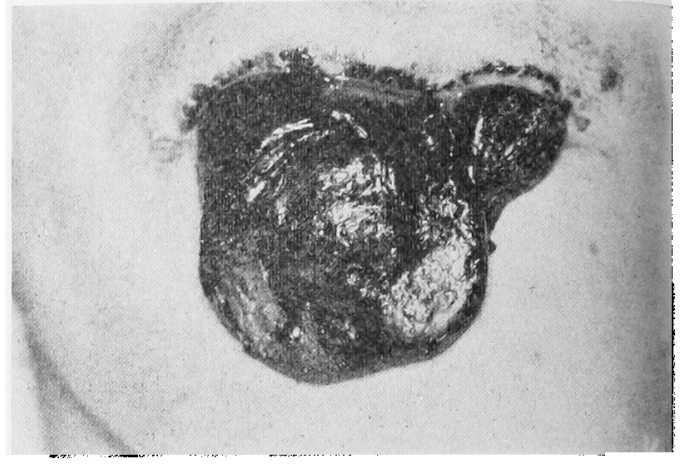

写真 13 11日後の盾瘍

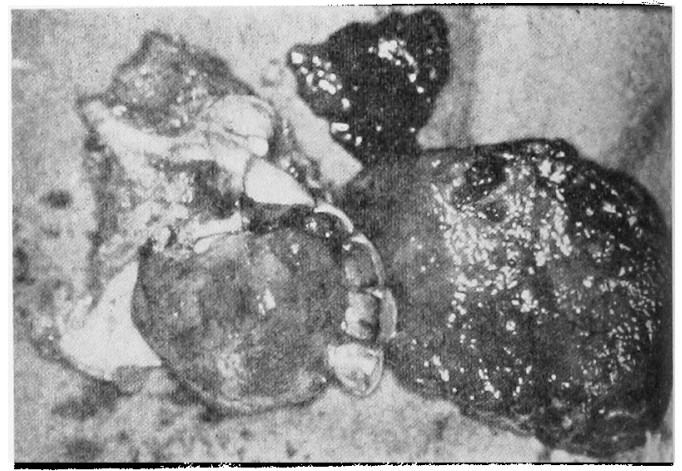

写真 14 切除塊（口蓝側からの写真）

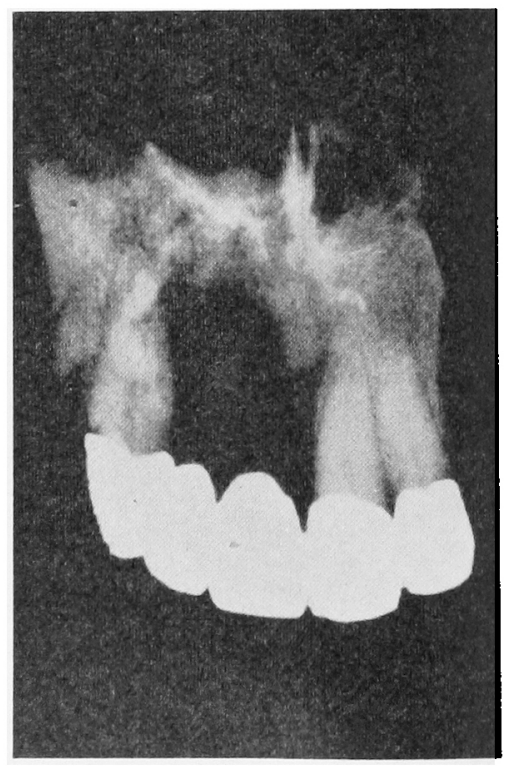

写真 15 切除塊の X線写真

部にも腫㻛が浸潤していた，随晹の割面は充実性で黄白 色を呈していた。 


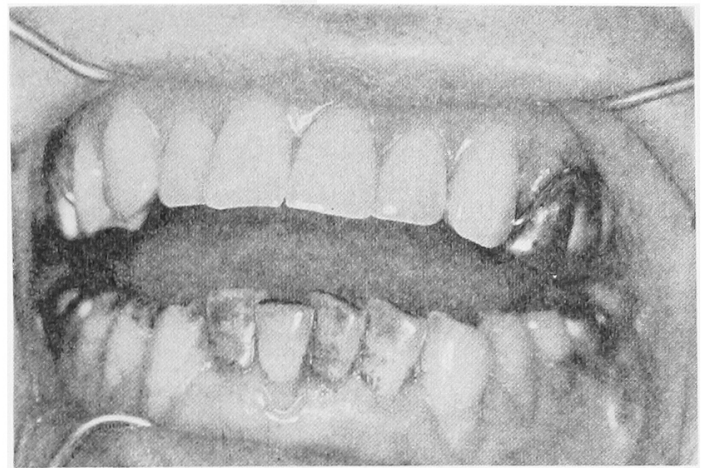

写真 16 義䫈装用(街後 5 か月)

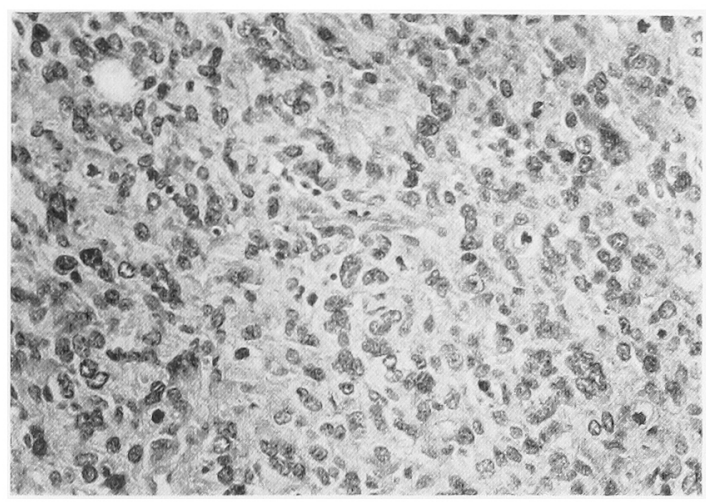

写真 17 組織学的所見 H-E 染色 $\times 200$ 組織球が增殖している部分。

なお，手術後20日目の7月田回までの15日間 に，合計 2,400 rads のコバルト照射を行った。

治療後の経過は順調で, 術後約 5 か月を経た現在, 再 発，転移形成の徵候はみられないので，義菌を装着し （写真 16），観察を続けている.

病理組織学的所見および診断 : 腫瘍は充実性で, 唇側 および口蓋側に有茥性に增殖しているばかりでなく，上 䝷骨内にも浸潤増殖していた。明瞭な被膜はなく，上顠 骨内の腫瘍の割面は黄白色であった.

腫㾨実質の大部分は組織球の增殖よりなっていたが （写真 17），一部には紡錘型の線維芽細胞が特徽的な走向 を示して增殖する storiform pattern 観察された(写直 18). 組織球は円形，扣よび類円形で，核の異型性す強 く，核分裂像が多く認められた，巨細胞も豊富で，核が 細胞質のほぼ中央に集合した Touton 型と思われる多 核巨細胞（写真 19）と，いわゆる bizarre な巨細胞 （写真 20）の2種類が観察された。銀染色に上る好銀 線稚子細胞間に多数存在しており（写真 21），亲た， oil red O 陽性細胞名散見された（写直 22）.

電子顕微鏡的所見：電顕的には, 組織球 (写真 23 ,

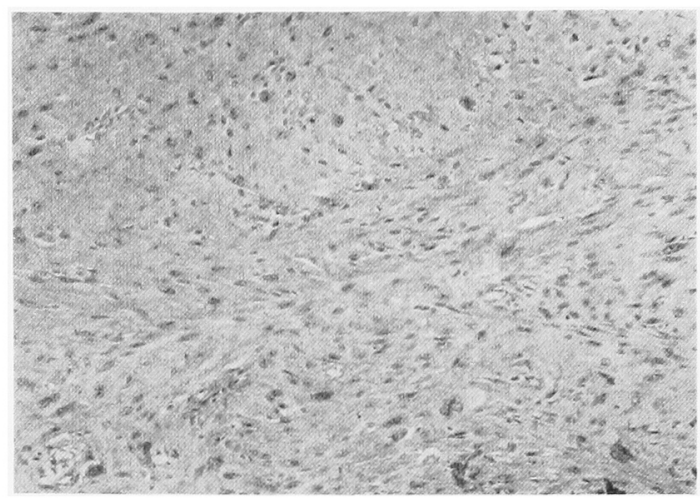

军真 18 組倳学的所見 H-E 染色 $\times 120$ 線踓芽細胞が走行を示して增殖する storiform pattern.

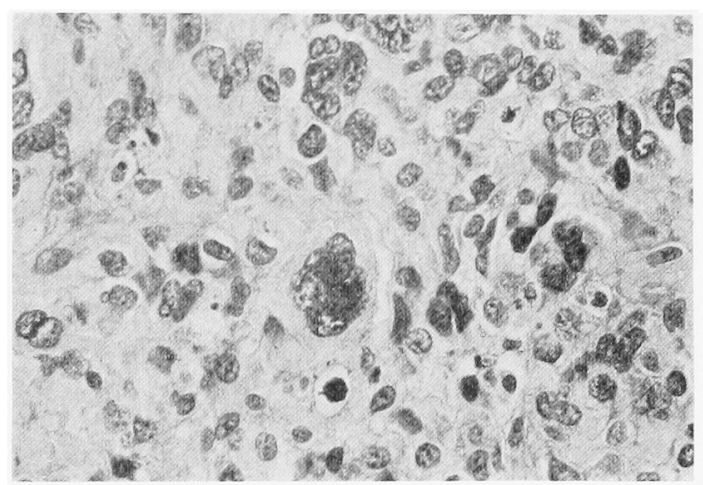

写真 19 組織学的所見 H-E 染色 $\times 500$ 核が中央に集まった多核巨細胞 (Touton 型).

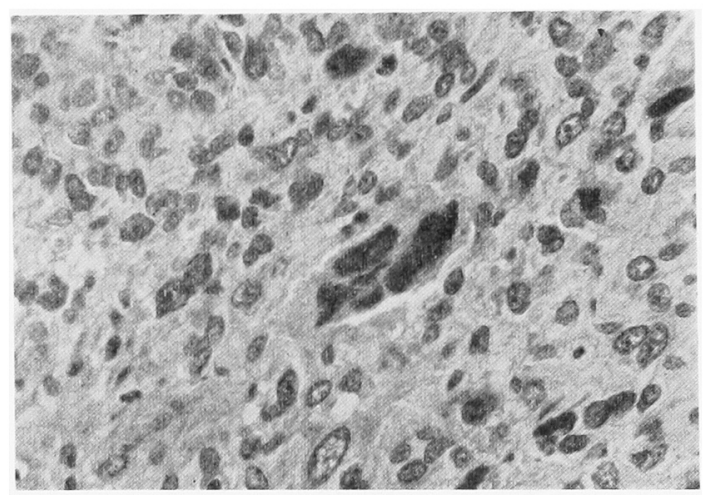

写真 20 組織学的所見 H-E 染色 $\times 500$

いわゆる bizarreな多核巨細胞.

24), 線維芽細胞（写真 23，25）, 黄色腫細胞（写真26） 牤よび多核巨細胞（写真 27）の4種類の細胞が 観察さ れ，それぞれに移行型がみられた。 


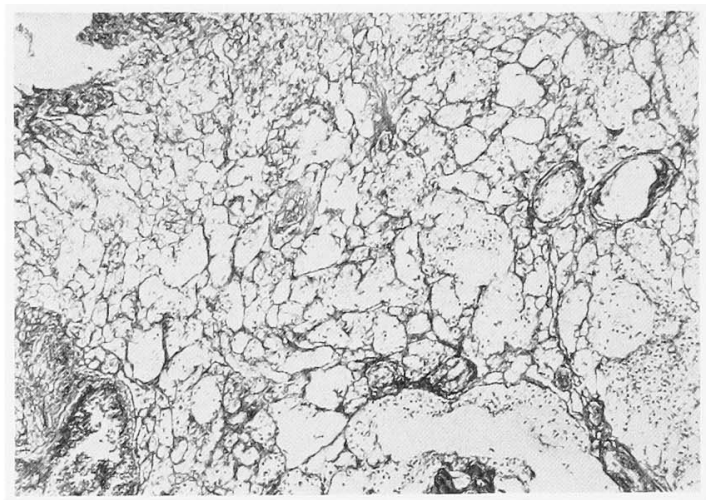

写真 21 組織学的所見 锠染色 $\times 120$

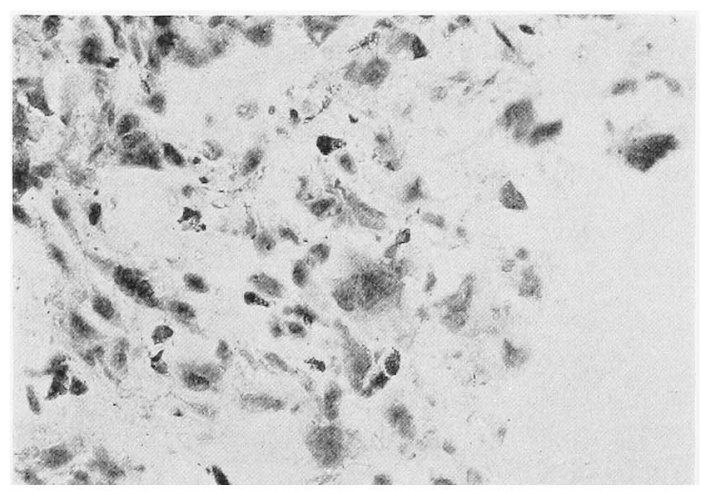

写真 22 組学的所見 oil red O 染色 $\times 200$

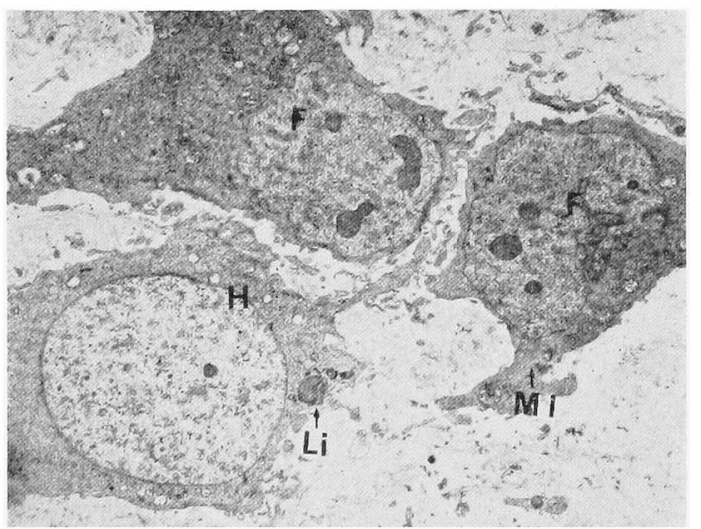

写真 23 電顕的所見 $\times 4,000$

線維芽細胞 (F) と組織球 (H) とがみられる，F には microfilament (Mi) が势められ，Hには lipid droplets (Li) が認められる。

以上の所見から本学口腔病理学教室の診断は悪性線維 珄組織球腫であった。

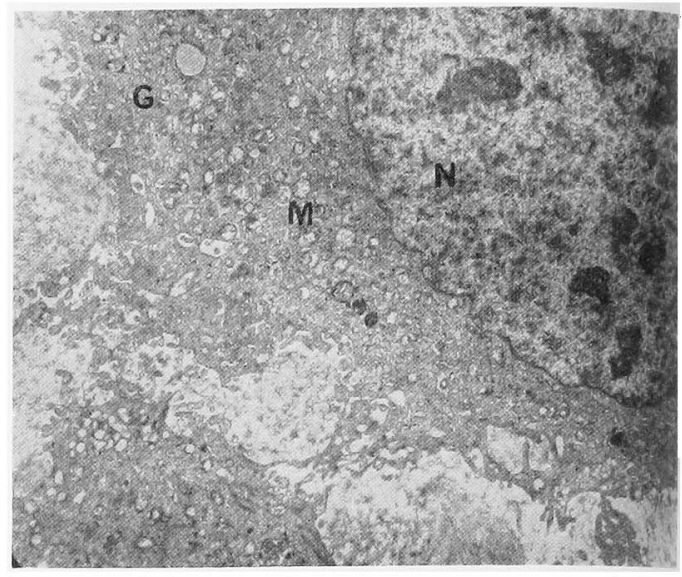

写真 24 電顕的所見 $\times 4,000$

組織球で，核は卵円形，Golgi 装置（G）および mitochondria (M) などの細胞内小器官が発達して いる，細胞表面より偽足をだしている.

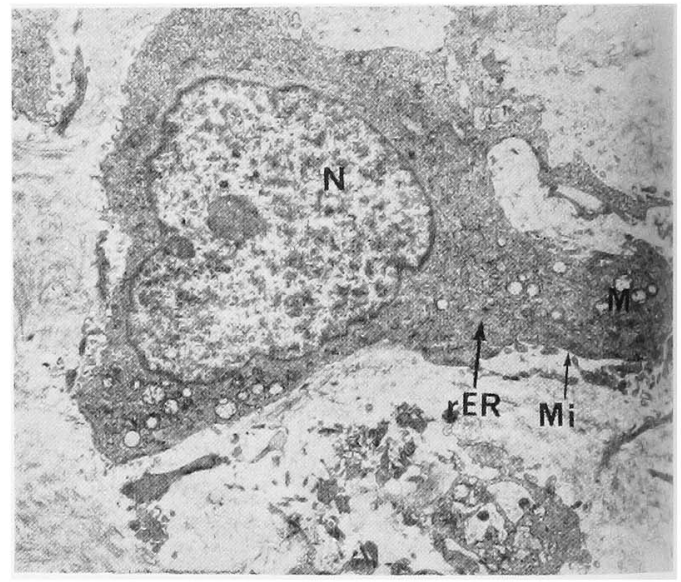

写真 25 電顕的所見 $\times 5,000$

線維芽細胞で，開大した粗面小胞体 (rER) が多く 認められる。

\section{考察}

線維性組織球腫は組織球の増殖を主体とする腫場です るが，細胞形態の多様性，巨細胞や泡洙細胞の有無むる いは銀線維や膠原線維の多室お゙よび配列の様相が著しく 異なるなど，多彩な組織像を示すことが多い，したが。 て本質的には共通なものでありながら，それぞれが独立 した entity のように考えられてきた。 1961 年に Kau

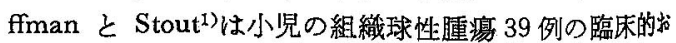
よび組織学的検討を行い，線維芽細胞の增殖を主体とす

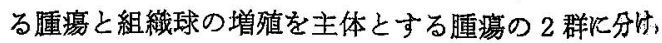




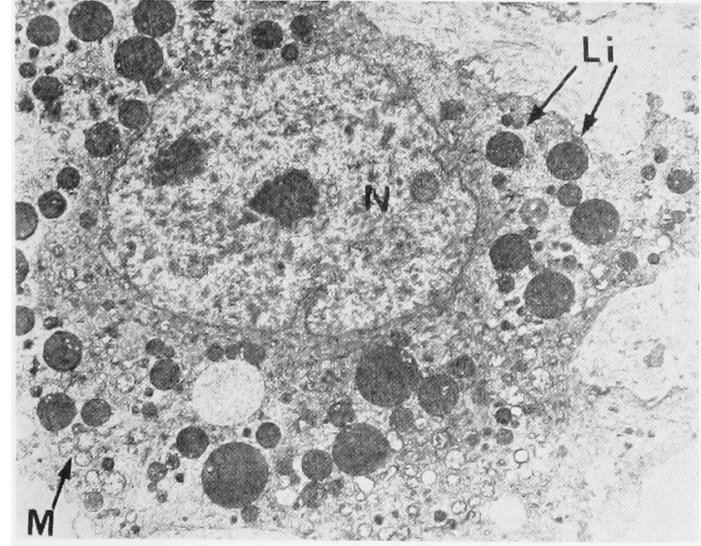

写真 26 電顕的所見 $\times 3,000$

黄色腫稩胞で，核の周囲に lipid droplets (L i) が 数多く認められ，また細胞内小器官るよく発達して いる。

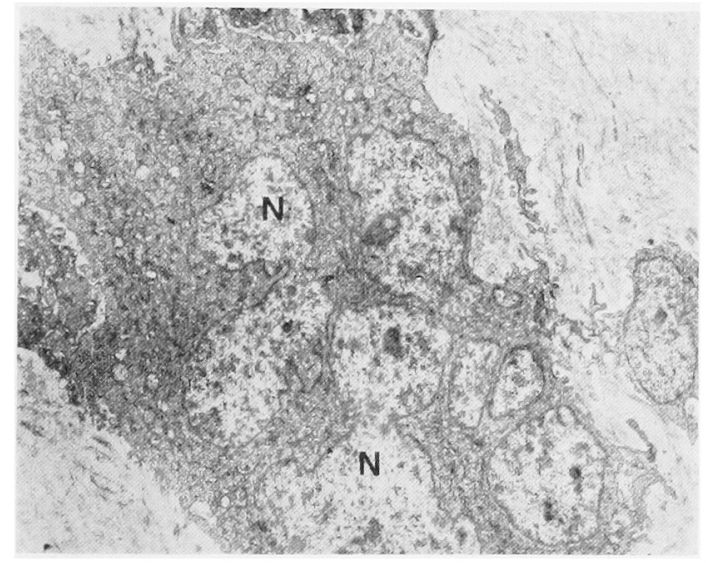

写真 27 電顕的所見 $\times 4,000$

多核巨勫胞で，3〜4 個の核を有し，科胞内小器官 は高度に発達している。

それぞれを fibrous xanthoma および histiocytoma と 命名した。 しかし，その後，組織培䖯法による in vitro での形態学的観察によって組織球が線維芽細胞に変貌す ることが報告され7)，組織球はその分化の程度あるいは 周囲の環境によって，その形態および機能が変化しらる facultive fibroblast としてとらえることが確認されてか ら，黄色腫を含めたこれら 1 群の腫瘍を総括しようとす る見解が提出されだ 10)（表 1 ）。湯本は，線維性組織 球腫は組織球の董媓性增殖を主体とし, 泡洙細胞拉よび 線維形成がみられるのが基本像であるとし，組織球から 泡沫細胞と線維形成への分化の方向を三角形で示し，泡 沫細胞側の頂点に Touton 型の多核巨細胞を，線 稚 形 成側の頂点に Bednar ${ }^{11)}$ が提唱した紡錨形細胞が車軸
表 1 線維性組織球腫の分類 ( Fu $\left.5^{10}\right)$

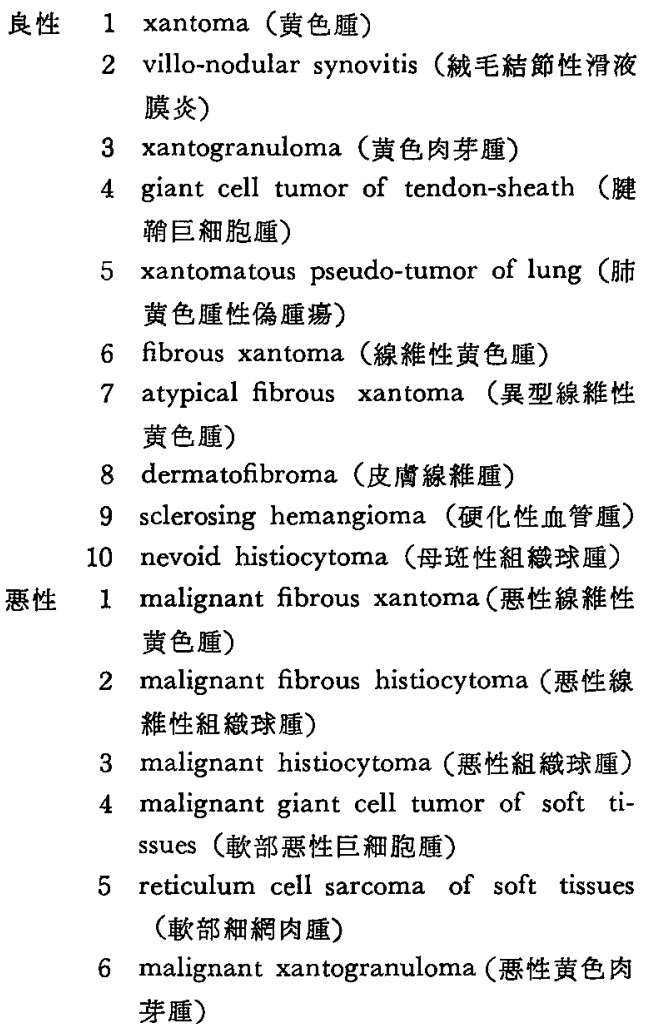

状に配列した特徽的な組織像である storiform pattern を想定した，組織球の増生を主体とするものが histiocytoma (組織球腫) であり，線維形成を主体とするすの が dermatofibro sarcoma protuberaus (隆起性皮膚線維 肉腫)であり，泡洙細胞の増殖を主体とするものが xanthoma（黄色腫）である，そして，それぞれの中間に fibro xanthoma (線稚性黄色腫), nevoid histiocytoma （母玟性組織球腫）および storiform fibrous xanthoma （花さしろ状線維性黄色腫）が位置するものと考点た.

また Enzinger ${ }^{12)}$ を心とする WHO (1969) の軟部 組織尰瘍の組織学的定義と分類では，本腫瘍は由来末定 の軟部尰癔群の中に入れられており，本邦に抋いて子悪 性軟部腫瘍研究班により組織学的分類が検討されつつあ るが ${ }^{13)}$ ，現在のところ組織学的分類はまだ確立されてい ない.

本尰痬の発生部位は組織型によって多少差があるが， 括もに四肢および軀幹で，口腔領域での発生は少なく， われわれが文献から涉椫乙得た線維性組織球腫は11例て ある，患者の年龄は新生罗から93歳をでに分布し，性別 では男性 6 例，女性 5 例で性別の差はみられない，一般 に小見に拉ける本腫瘍は良性型が多いとされ 
表 2 口腔頒域の楾維性組織球腫の叝告怔例

\begin{tabular}{|c|c|c|c|c|c|c|c|c|c|c|}
\hline & No & 䇏 断 名 & 年齿 & 吽: 別 & 部 位 & 大寺巳 $\mathrm{cm}$ & 治㙩法 & $\begin{array}{l}\text { 病理組織登: } \\
\text { 的特徵 }\end{array}$ & 予 後 & 報 告 者 \\
\hline \multirow{5}{*}{ 良 } & 1 & 良性:組織球腫 & 4 週 & $\hat{o}$ & 口唇部 & $1.0 \times 1.4$ & 摘 出 & $\begin{array}{l}\text { 多角形心組織 } \\
\text { 球の增殖 }\end{array}$ & $\begin{array}{c}\text { (3 年 } 8 \text { 力月) } \\
\text { 良 好 }\end{array}$ & Kauffman \& \\
\hline & 2 & "1 & 5 歳 & $q$ & "1 & 1.0 & "1 & & $\begin{array}{c}(2 \text { 年 } 3 \text { か月) } \\
\text { 良 好 }\end{array}$ & Stout ${ }^{1)}$ \\
\hline & 3 & 線維性蒖色腫 & $58 \prime \prime$ & ๆ & 賢部 & 小 & "1 & storiform 型 & $\begin{array}{l}\text { (6 加月後再価) } \\
\text { 再手術良好 }\end{array}$ & \multirow{4}{*}{$\begin{array}{l}\text { O'Brien \& } \\
\text { Stout }^{2)}\end{array}$} \\
\hline & 4 & "1 & $39 \prime \prime$ & $\hat{o}$ & 䫂下腺部 & $4.5 \times 3.2 \times 2$ & " & "1 & ( 9 か月) 良好 & \\
\hline & 5 & "1 & $50 \prime$ & $q$ & 嫃部 & 小 & "1 & 巨細胞型 & （2 年）良好 & \\
\hline \multirow[t]{3}{*}{ 性 } & 6 & " & $65 \prime \prime$ & $\hat{\delta}$ & 耳下腺劋 & $3.2 \times 1.7 \times 2.2$ & "1 & 混合型 & (9か月) 良好 & \\
\hline & 7 & 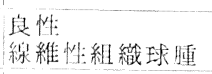 & $\begin{array}{l}\text { 新生 } \\
\text { 巟 }\end{array}$ & 우 & 下顎部 & 4.5 & " & storiform 型 & 良好 & Albright $b^{5)}$ \\
\hline & 8 & " & 32 藏 & 운 & 舌部 & $6 \times 5 \times 5$ & "1 & 組織球の增殖 & $\begin{array}{r}(1 \text { 年 } 6 \text { 力月 }) \\
\text { 良好 }\end{array}$ & 堀越 5 \\
\hline \multirow{3}{*}{ 悪 } & 9 & 患性 & $78 \prime \prime$ & $\hat{o}$ & 䁰部 & $0.5 \times 2.5$ & " & storiform 型 & $\begin{array}{l}4 \text { 回再热 } \\
\text { 肺等に転移死亡 }\end{array}$ & $\begin{array}{l}\text { O'Brien \& } \\
\text { Stout }^{2)}\end{array}$ \\
\hline & 10 & 恐惟 & $93 \prime \prime$ & $\hat{o}$ & 下擷部 & 1. $4 \times 12.9 \times 7$ & 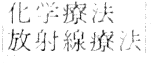 & 此合型 & 死亡 & Solomon $5^{3)}$ \\
\hline & 11 & $\begin{array}{l}\text { 炎痱性: } \\
\text { 線䧽性: 組織球腫 }\end{array}$ & $81 " \prime$ & $\hat{o}$ & 口底部 & $3 \times 4$ & 放的楾撞法 & 三組胞犁 & 肺等に忶移死亡 & $\begin{array}{l}\text { Kyriakos \& } \\
\text { Kempson }\end{array}$ \\
\hline \multirow[t]{2}{*}{ 性 } & 12 & $\begin{array}{l}\text { 䏇性: } \\
\text { 線維性:組織球腫 }\end{array}$ & $23 \prime \prime$ & ㅇ & 顎问節郬 & $2 \times 2 \times 3$ & 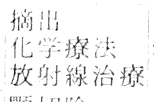 & 泥合型 & ( 2 年) & 吉村 $5^{6)}$ \\
\hline & 13 & " & $50 \prime$ & $\hat{o}$ & 上顎部 & $4 \times 3 \times 2.5$ & $\begin{array}{l}\text { 喕切除 } \\
\text { 放的線療法 }\end{array}$ & " & ( 6 力月) 良好 & 堀越 5 \\
\hline
\end{tabular}

表 3 線維性組緎球腄の再帒扣よび転移染 (Solomon $5^{3)}$ )

\begin{tabular}{|c|c|c|c|c|c|}
\hline \multirow{2}{*}{$\begin{array}{l}\text { 城告者拈よび } \\
\text { 報告年度 }\end{array}$} & \multirow{2}{*}{ 症例数 } & 再 & 热 & 車 & 移 \\
\hline & & 件数 & $\%$ & 件数 & $\%$ \\
\hline $\begin{array}{c}\text { O'Brien \& Stout } \\
(1964)\end{array}$ & 53 & 16 & 30 & 13 & 25 \\
\hline $\begin{array}{l}\text { Kempson \& } \\
\text { Kyriakos (1972) }\end{array}$ & 30 & 9 & 30 & 3 & 10 \\
\hline $\begin{array}{c}\text { Soule \& Enriquez } \\
\text { (1972) }\end{array}$ & 33 & 10 & 33 & 10 & 33 \\
\hline
\end{tabular}

型4 例はすへて成人に発生したものである。また病理組 䄉学的には storiform pattern を走与もの书よび下紐胞 が認められるものが多い上らである。治療法は艮性型の 場合には完全摘出で，口腔领域ても良性の7例は子後良

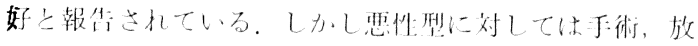

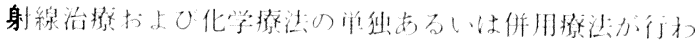

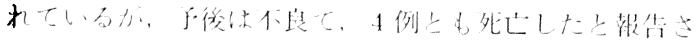

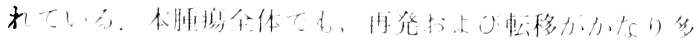

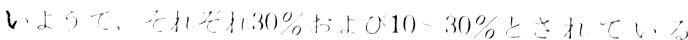
(表 3$)^{2,11,1 ;}$

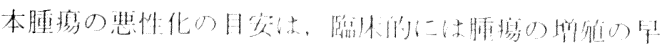

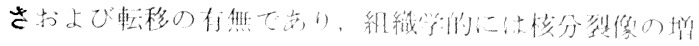

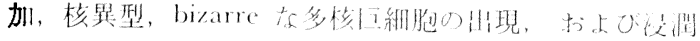
性增殖が重要な子がかり上されているが2,3,15), 組䋐学:
的所見々陵床的経過とは必ずしも一致しないこともある よ5で, 今後の問題としてさらに詳細な検討が必要で勾 ろら.

われわれが経験した症例 1 は，腫㹉は $6 \times 5 \times 5 \mathrm{~cm}$ の 大きなものであるが，その增大速度はかなり緩慢で岁 り, 被膜を有し, 病理組織学的にも大部分が類円形の組 織球の增殖であり，一部に環状に核が配列した多核巨檤 胞が散見されたが， bizarre な巨細胞は久られず悪性の 所見は認められなかった。また一部に oil red O 染色が 陽件の組織球が認められたが，これと同様の所見は Kauffiman ${ }^{12}$ らの小昌の良性線維性組織球腫にも観察されて いる，以上の所見から本胢境は湯本の分類 1$)^{9)}$ に相当

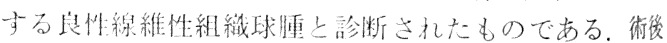

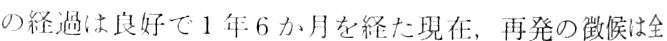
く諗めら九ない.

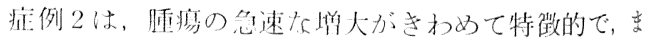

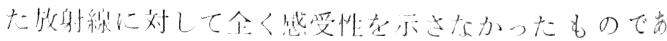

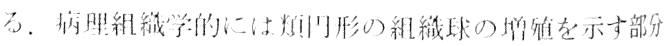

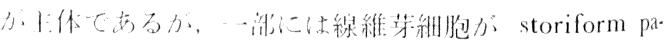

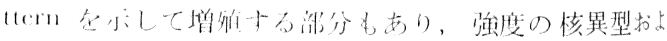

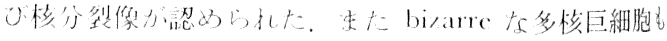

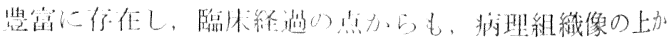

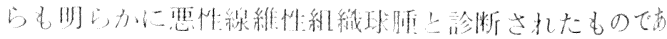
万.

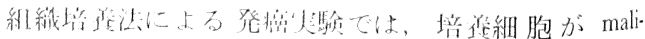
gnant transformation 在起こすと絒胞の邽列が乱れ，交 
錯して増殖することが報告されている年 18)。 これは本 腫湯における storiform pattern の出現と共通する点が あるのではなかろらかと推測される。この意味におい て，良性の症例では線維芽細胞は平行的な配列を示して 増殖しており, 一方, 恶性の症例ではs storiform pattern が認められているので, 両者の所見を比較すると興味深 いと考えられる.

悪性線維性組織球腫の予後については, 上記のように 再発および転移例が多く, 予後も全体的には不良と報告 されているので，われわれの症例についても慎重に子後 を追跡していきたい.

\section{結語}

われわれは34藏女性の舌部に発生したかなり大きな良 性線維性組織球腫と, 50歳男性の右上顎骨前歯部に発生 した悪性線維性組織球腫の各 1 例を経験した。いずれも 口腔領域にはまれな腫汮であるので，その概要を報告 し，あわせて文献的考察を行った。

本報告症例の組織学的所見怙よび診断は本学口腔病理 学教室石川梧朗教授, 小守昭助教授扣よび高木 实博 士のこ教示によるものであり，㩱意を表します。

\section{文献}

1) Kauffman, S.L., Stout, A.P.: Histocytic tumors (fibrous xantoma and histiocytoma) in children. Cancer 14: 3681957.

2) O'Brien, J.E., Stout, A.P.: Malignant fibrous xanthomas. Cancer 17: 14451964.

3) Solomon, M.P., et al.: Malignant fibrous histiocytoma of the soft tissues of the mandible. Oral Surg 35: 6531973.

4) Kyriakos, M., Kempson, R.L.: Inframatory fibrous histiocytoma. Cancer 37: 15841976.

5) Albright, J., et al.: Mandibular jubenile fibrous histiocytoma with ossification. J $\max$ fac Surg 4: 1201976.

6) 吉村安郎, 他: 顎関節部に発生した悪性線䧽性 組織球腫の 1 症例。 日口外誌 22：847 1976.
7) Ozzello, L., et al.: Cultural characteristics of malignant histiocytomas and fibrous xanthomas. Cancer 16: 3321963.

8) Stout, A.P., Lattes, R.. Tumors of soft tissues. Atlas of tumor pathology. Fasc. I. Washington, D.C. Armed Forces Institute of Pathology. 1967, p 107.

9）湯本東吉：線䧽性組織球腫について。臨整外 8: 6981973.

10) Fu, Y-S., et al.: Malignant soft tissue tumors of probable histiocytic origin(Malignant fibrous histiocytomas): General considerations and electron microscopic and tissue culture studies. Cancer 35: 1761975.

11) Bednar, B.: Storiform neurofibromas of skin, pigmented and non-pigmented. Cancer 10: 3681957.

12) Enzinger, F.M., et al.: Histological typing of soft tissue tumors. No. 3 WHO Genova, 1969, p 40.

13）佐野量造：悪性軟部腫劰の組織学的分類, 特に その鑑別診断について。 日整会誌 49: 157 1975.

14) Soule, E.H., Enriquez, P.: Atypical fibrous histiocytoma, malignant fibrous histiocytoma, malignant histiocytoma, and epithelioid sarcoma. Cancer 30: 1281972.

15) Kempson, R.L., Kyriakos, M.: Fibroxanthosarcoma of soft tissues. A type of malignant fibrous histiocytoma. Cancer 29: 9611972.

16) Yumoto, T., at al.: Malignant fibrous histiocytoma of bone. Acta Path Jap 26: 295 1976.

17) Kamahora, J., Kakunaga, T.: In vitro transformation of hamster whole embryonic cells by 4-nitroquinoline-1-oxide. Biken J 9: 295 1966.

18) Namba, M., et al.: Carcinogenesis in tissue culture IX: Malignant transformation of cultured rat cells treated with 4-nitroquinoline-1 -oxide. Japan J Exp Med 39: 2531969.

19) Bhaskar, S.N.: Oral tumors of infancy and childhood: A survey of 293 cases. J Pediat 63: 1951963. 